\title{
Enforcement of Regulations in Medical Gas Management in Indonesia
}

\author{
Efrila \\ Doctoral Student of Jurisprudence \\ University of Borobudur \\ Jakarta, Indonesia \\ efrila66@y ahoo.co.id
}

\begin{abstract}
Medical gas is an energy resources deem as necessary for human survival. Medical gas may be beneficial to human survival if properly managed and used as required, but this medical gas may pose a danger or risk if its management is not carried out properly because of the nature of the medical gas that readily reacts with other materials and that are not appropriate with the environments. Medical gas in the world of health is needed to cope the emergency, health care, to cure diseases, and to assist the process of anesthesia in the operating room. In other circumstances due to mismanagement of management or reacting with unsuitable environments then medical gas may cause shortness of breath or other illness. For that we need good and correct management.
\end{abstract}

The existence of balanced benefits and risks for human life, the management of medical gas is very important, so this writing is intended to know the regulation of the management of existing medical gas, but also see who is responsible for the management of medical gas, and things that are not equally important is to see how the supervision in medical gas management. The management of medical gas required rules that are not less important is the enforcement of these rules, so that management run in accordance with service standards and standard procedures to minimize and avoid the danger / risk that may arise.

Keywords-benefits, risk dan management of medical gas

\section{INTRODUCTION}

Medical gas is one of the resources needed to support life in the world of health to sustain life through the treatment and / or care of the sick. Medical gas is a vital ingredient indispensable for patient survival, but it is also very dangerous for patients especially as well as for those around them in case of mismanagement in management.

Management of medical gas and supervision in the management is very necessary given the habit of human beings who become culturally as often negligent in doing their duties that can cause danger and even death, with the result the implementation is always required rules as a technical guidance implementation to avoid the emergence of unwanted impacts. Guidance and supervision of all activities related to the implementation carried out by the Public health office in the district or city, in performing its duties may involve several other agencies. By observing this problem whereby medical gas has the function required for survival but in certain circumstances can be life-threatening, it is very necessary to have governance rules so that negative impacts that may arise can be avoided. It is also required enforcement of the rules in the management of medical gas from the source up to use to maintain human life.

Medical gas required facilities and health care facilities such as hospitals, because medical gas is used to maintain the human life span the medical gas to be used must meet the requirements such as must be clean, not contaminated, and should not be wrong in the use. The types of medical gas used in the medical world to maintain patient survival include Oxygen (O2), Nitrogen $(\mathrm{N})$, Dinitrogen Oxide (N2O), Carbon Dioxide (CO2), Medical Compressed Air (Breathing Air). Each type of medical gas has different functions such as to help and maintain breathing, surgery, anesthesia, and others. The use of medical gas should always be in accordance with the needs, because medical gas is very dangerous and can even cause death if its use is not appropriate medical indication. Therefore, good governance is needed from the sources of production, procurement, storage, distribution and uses.

Medical gas management system, focused on health facilities or medium so that from the provision of health service facilities and infrastructure that use medical gas up to the supervision of the use is done by the ministry of health alone. Medical gas management systems in health care facilities such as hospitals are conducted centrally or noncentral, both of which have advantages and disadvantages that require supervision from procurement to use. In order to effectively benefit patients in need and not cause adverse impact on the health of patients and others around them.

\section{A. Problem}

Medical gas is needed in the medical world that has the function to maintain life and cure diseases when given or used in accordance with medical needs, but medical gas is also a material that can cause death when used not in accordance with the needs. In addition, medical gases can pose a hazard if not managed properly, therefore it is needed to know:

1. What is the regulation of medical gas management?

2. Who is responsible for the management of medical gas?

3. How is the supervision in medical gas management?

\section{B. Theoritical Basis}

Medical gas is a gas type element with special specifications used for the treatment and care for the survival of sick patients. The understanding of medical gas and its installation as contained in Article 1 the decree of the 
Minister of Health of the Republic of Indonesia No. 1439/Menkes/SK/XI/2002 About The Use of Medical Gas On Health Care Facilities. In this article it is mentioned that Medical Gas is a gas with special specifications used for medical services at health facilities. The types of medical gases used to as sist the survival and health maintenance are:

\section{Oxygen $(\mathrm{O} 2)$}

It is a medical gas that is always available at health care facilities used as first aid in emergencies in patients who are shocked by heart and blood vessel abnormalities, lung disorders, severe trauma, or other disorders requiring adequate oxygenation.

\section{Nitrogen $(\mathrm{N})$}

It is a medical gas used for the treatment of skin tumors cryotherapy, also used in the manufacture of drugs, and serves sebgai mix of other medical gas for lung function tests.

\section{Dinitrogen Oxide (N2O)}

It is a medical gas widely used in surgery as an analgesic (pain reliever) or anesthesia.

\section{Carbon Dioxide $(\mathrm{CO} 2)$}

It is a medical gas used for less invasive surgery, and for respiratory stimulation before or after anesthesia.

5. Medical Air resulted from compressed air used by health facilities such as hospitals to distribute medical gas. Compressed air can be used as a medical air or as a toolmaker, such as a breathing apparatus.

In addition to having good benefits for health, problems can also arise in the handling of medical gas. The medical gas that can cause danger there are several categories, namely:

- Permanent, where the gas state settles below normal temperature,

- Liquefiable, gas is supplied below normal temperature,

- Cryogenic, the gas provided is stored at very low temperatures.

The dangers / risks posed by medical gases are largely undetectable due to the colorless, tasteless, and sometimes odorless nature of the gas. The nature of this medical gas is very dangerous because it can rarely be detected without the equipment and monitoring.

Apart from the nature of the medical gas itself, the hazards / risks can arise due to pressure that is not in accordance with the standards, therefore it is very important to pay attention to the pressure on which gas is stored and used.

By looking at the notion of medical gas and its types and functions, the medical gas and its installation must have higher safety standards than gas or other gas installations. This is because the use and distribution of medical gas in health care facilities is used for the purpose of health services. The things to note before and after medical gas used are:

1. Medical Gas Pipe Installation is a set of piping infrastructure along with equipment providing certain medical gas required to deliver medical gas to the point of outlet of the room of action and treatment;

2. Central medical gas is a set of infrastructure and equipment and or gas/liquid tube which stores certain medical gases which can be channeled through medical gas installation pipes;

3. Medical Gas Installation is a central set of medical gas, medical gas pipe installation to outlet.

Medical gas management system that is central and noncentral system. Central medical gas system management should pay attention to:

- Storage (central space), must be safe from hazards that may interfere with health care activities. Centrally located space away from heat sources and the like to avoid friction that can cause an explosion or fire.

- Distribution, from the central chamber to medical gas outlets. All medical gas installations in distribution should use tools and materials that meet medical requirements such as the type of pipe used, generally using copper or stainless steel pipes.

Non-centralized medical gas management systems, ranging from procurement, storage, and distribution are fragmented systems, in which:

- Procurement, obtained from the manufacturer of medical gas in ready-to-use conditions that meet medical requirements.

- Storage, in storage space away from heat or oil sources or the like. The storage location must be special and each type of gas is distinguished, as well as the way tube storage should be kept in standing position and equipped with a security device.

- Distribution, manually brought near to the patient and use of medical gas arranged using flow meter with the rules as needed and certain time.

Taking into account the above description, special and clearer arrangements are necessary in the management of medical gas because medical gas is needed for human survival but is also a dangerous element. Related rules are made for the benefit of human beings with the purpose of protection for the public interest, individual interests, as well as the interests of society both users and managers. These rules must be obeyed and carried out for the sake of common safety.

From several scientific papers found, Policies on enforcement of medical gas management regulations include:

1. Regulation of storage and handling of cylindrical tubes and oxygen and nitrous oxide containers.

2. Regulation of safe handling of oxygen and nitrous oxide in anesthetic room/locations. Evaluation of any warning signal and all the quick effort required to restore the proper functioning of the medical gas system.

3. Organizational and resource capabilities to address the total cessation (loss) of each systemand medical gas.

4. All tests required in system verification shall be effected successfully before the use of any medical gas piping systemfor patient care. 
Towards the materials that are useful or harmful to human life or society in general need to be made legal rules for the protection of the interests of society. There are some public interests that are protected by law through rules policies that are:

1) Public interest for public safety, such as security, health, and welfare, guarantee transactions and income

2) The interests of social institutions

3) The public interest against moral damage

4) Community interest in social protection and protection against abuse of rights

5) Public interest in general progress

6) The public interest in individual human life.

The service to the use of medical gas belongs to the public health service group which is an essential element in the implementation of government functions, therefore the government is obliged to provide good related services in order to provide benefits to the community and to prevent the community from possible harm. To ensure that the service process runs consistently, service standards and standard operating procedures are required. Establishment of service standard is done through identification process of service type, customer identification, customer expectation indication, vision and mission formulation service, process and procedure analysis, facility, infrastructure, time and service cost. In addition, standard operating procedures are required to ensure that service standards are carried out in accordance with other relevant legal rules and to avoid irregularities that may pose harm to both users and managers themselves.

Enforcement of rules that is the process of efforts for the establishment or functioning of norms of rules as a guideline of behavior in the life of society and state. Rules are made for the purpose of protecting and providing certainty to the users and administrators of things including one of which is medical gas. The enforcement of rules related to an activity is the relevant institution and its apparatus which is regulated in the rules relating to such activities. Rules on the management and use of medical gases found therein:

1. Constitution (Undang-Undang) of the Republic of Indonesia No. 44 Tahun 2009 on hospital, in article 7 and article 11 which regulates the requirements of infrastructure and hospital buildings

2. Regulation of the Minister of Health of the Republic of Indonesia No. 24 Tahun 2016 on the technical requirements of Hospital Building and Infrastructure

3. Regulation of the Minister of Health of the Republic of Indonesia Nomor 4 tahun 2016 on the use of medical gas and medical vacuum at health service facilities

\section{Methodology}

Research methodology here is empirical normative research, where the data used is secondary data from various literature in the form of regulations, books, and related scientific writings.

\section{DISCUSSION}

Medical gas have enormous benefits for the survival of humans where each type has a usefulness for different diseases as well as the above explanation. However, medical gas also has a good risk due to errors in the management, because of the nature of the medical gas itself, as well as due to environmental changes. Dangers that may arise include:

1. Coldburn, skin burns from contact with cold gas for too long (medical gas with a temperature below 180 degrees)

2. Asphyxiate, can be caused by oxygen deprivation but can also result from inhaling other medical gases such as Nitrogen, Nitrous Oxide, Carbon Dioxide, and helium

Some cases have occurred when the use of medical gas in hospitals and occurred in several countries namely Austria, Germany, and Switzerland. These cases occur in the operating room where the patient dies by inhaling Nitrous Oxide, this is due to the misconnected oxygen pipe with nitrous oxide on the anesthesia machine. A similar case also happened in Indonesia precisely in one of Bengkulu hospitals in 2001, the same year occurred in one of the largest hospital in Bandung, in 2003 also occurred in one of the leading hospital in Jakarta. By looking at these cases, it is clear that the rules in the management and use of medical gas should be enforced so that possible medical hazards and risks can be avoided.

Public policy on either chemicals deemed as a necessity or as a danger is needed for the protection of the community. Policies or rules on medical gas that include chemicals are regulated within the scope of health policy, where related rules include:

1. Constitution (Undang-Undang) of the Republic of Indonesia No. 44 Tahun 2009 on hos pital, which govern the requirements of infrastructure and hospital buildings where one of them is a medical gas installation. Requirements include:

- Must meet the standards of service, security, and hos pitalhealth and safety standards.

- Must be well maintained and on functioning condition.

- Should be done by officers who have competence in the field.

- Should be documented and evaluated periodically and continuously.

2. Regulation of the Minister of Health of the Republic of Indonesia No. 24 Tahun 2016 on the technical requirements of Hospital Building and Infrastructure aims to:

- Establish Hospital Infrastructure that is functional and in accordance with the order of buildings and infrastructure that harmonious and harmonious with the environment;

- Realizing orderly management of buildings and infrastructure that ensures the technical reliability of buildings and infrastructure in terms of safety, health, comfort, and convenience; and

- enhancing the participation of government, local governments and communities in hospital management in accordance with technical require ments. Regulation of the Minister of Health of the Republic of Indonesia No. 24 Tahun 2016 on Hospital Technical Requirements for Building and Infrastructure 
Article related medical gas is article 25 that is:

1) The installation of medical gas and medical vacuum include:

a. Medical gas and medical vacuum sources;

b. Piping network of medical and medical vacuum system; and

c. Terminal on medical gas and medical vacuum system.

2) The sources of medical gas and medical vacuum as referred to in ayat (1) include:
a) Medical cylinder;
b) Oxygen concentrator;
c) Air compressor;
d) Vacuum pump; and
e) Waste discharge pumps of anesthetic gas.

3) The medical cylinder as referred to in ayat (2) the letter a includes gas cylinder, liquid gas cylinder (PGS), and liquid (cryogenic) container.

4) The piping network of the medical gas and medical vacuum systems as meant in this article include:
a) Valve;
b) Factory-made assemblies;
c) Medical gas rail mounted on the surface;
d) Pressure and vacuum indicators;
e) Warning system;
f) Distribution; and
g) Naming and identification.

5) The terminals of the medical gas and medical vacuum systemreferred to include:

a) outlet and inlet stations; and

b) tubular regulator, which is used directly to the patient through a medical gas tube.

6) Further provisions concerning the installation of medical and medical vacuum at the Hospital shall be carried out in accordance with the provisions of the laws and regulations.

3. Regulation of the Minister of Health of the Republic of Indonesia Nomor 4 tahun 2016 concerning the use of medical gas and medical vacuum at health service facilities, in Article 1 in this Ministerial Regulation:

1) Medical Gas are gas with special specification which is used for medical service at health service facility.

2) Medical Vacuu m is a tool with special specification which is used to suck body fluids on medical service in health care facility.

3) Medical Gas and Medical Vacuum Installation System is a central device of medical gas and medical vacuum, pipeline installation, check valve and medical gas alarm to medical outlet point and medical inlet.

4) Oxygen Concentrator is the Oxygen separator in the air $(21 \%)$ with Nitrogen in the air $(78 \%)$ and other gas $(1 \%)$. The output of this machine is Oxygen with a minimum concentration of $90 \%$.
Based on Regulation of Minister of Health of the Republic of Indonesia No. 4 Tahun 2016 on the Use of Medical Gases and Medical Vacuum on Health Service Facilities, Article 10 The Minister, Governor, Regent/Mayor shall supervise the implementation of the Regulation provisions on the use of medical gas and medical vacuum. In conducting guidance and supervision may include relevant professional organizations and associations. Technically the rules related to the use and management of medical gas are policies of the health sector so that the guidance and supervision of all activities related to the use and management of medical gas is carried out by the District Health Office / City, where in conducting guidance and supervision may involve various agencies other related and professional health organizations.

Guidance and supervision made by relevant agencies in accordance with the prevailing regulation namely Permenkes RI No. 4 Tahun 2016 in the form of coaching is by doing advocacy and socialization, provision of guidance, supervision, monitoring and evaluation, consultation, and / or education and training. While supervisory activities by the Minister, Governor, Regent / Mayor in accordance with their respective authorities may provide administrative measures carried out in accordance with the provisions of legislation in the form of; oral warning, written warning, and / or revocation of permit.

\section{CONCLUSIONS}

By looking at the above description can be concluded that medical gas is one element of energy that is needed and useful for human survival. However, medical gas may also pose a risk/hazard to human health and safety if its use and management are not properly performed. In order for medical gas can always be a necessary source without risk, the solution must be done to conduct supervision up to enforce existing legislation. The rules associated with medical gas are:

1. Constitution (Undang - undang) of the Republic of Indonesia No. 44 Tahun 2009 about hospital.

2. Regulation of the Minister of Health of the Republic of Indonesia No. 24 Tahun 2016 on the technical requirements of Hospital Building and Infrastructure

3. Regulation of the Minister of Health of the Republic of Indonesia Nomor 4 tahun 2016 on the use of medical gas and medical vacuum at health service facilities.

Regulations related to medical gas are health products, so the guidance and supervision is carried out by the local government through the regional health agency, although the supervis ory agency and the supervisor of the District Health Office may involve the organization or association of the health profession.

The forms of coaching and supervision of medical gas are; coaching by advocacy and socialization, guidance, supervision, monitoring and evaluation, consultation, and / or education and training. While the form of supervision is that it can provide administrative actions carried out in accordance with the provisions of legislation in the form of; oral warning, written warning, and / or revocation of permit. 


\section{REFERENCES}

[1] Ade Saptono, 2017, Budaya Hukum dan Kearifan Lokal; Sebuah Perspektif Perbandingan, FHUP Press, Jakarta.

[2] Anonim, 1994, Pedoman Instalasi Gas Medik, Direktorat Jenderal Pelayanan Medis Direktorat Instalasi Medik Departemen Kesehatan Republik Indonesia.

[3] Anonim, 2012, Pedoman Teknis Prasana Rumah Sakit Sistem Instalasi Gas Medisk dan Vakum Medik, Direktorat Bina Upaya Kesehatan Kementerian Kesehatan Republik Indonesia.

[4] Budi Winarno, 2016, Kebijakan Publik Era Globalisasi, CAPS, Yogyakarta.

[5] Faisal Santiago, 2016, Bunga Rampai Catatan Hukum, Cintya Press, Jakarta.

[6] Faisal Santiago, 2012, Pengantar Hukum Bisnis, Mitra Wacana Media, Jakarta.

[7] Jimli Assiddiqie, Penegakan Hukum, Mahkamah Konstitusi Republik Indonesia.

[8] Zudan Arif Fakrulloh, 2014, Hukum Indonesia Dalam Berbagai Perspektif, Rajagrafindo Persada, Jakarta.
[9] Undang-Undang Republik Indonesia No. 44 Tahun 2009 tentang Rumah Sakit

[10] Peraturan Menteri Kesehatan Republik Indonesia No. 4 Tahun 2016 tentang Penggunaan Gas Medik dan Vakum Medik pada Fasilitas Pelayanan Kesehatan

[11] Peraturan Menteri Kesehatan Republik Indonesia No. 24 Tahun 2016 tentang Persyaratan Teknis Bangunan dan Prasarana Rumah Sakit

[12] Keputusan Menteri Kesehatan Republik Indonesia Nomor 1439/Menkes/SK/XI/2002 tentang Penggunaan Gas Medis Pada Sarana Pelayanan Kesehatan

[13] Albert, Penyimpangan-penyimpangan Pada Instalasi Gas Medis Pada Sarana Pelayanan Kesehatan, https://www.scribd.com/doc

[14] Anonim, Pengoperasian dan Manajemen dalam Instalasi Gas Medis, https://gasmedisrs. wordpress.com

[15] Anonim, Jenis-Jenis Gas Medis dan Fungsinya, https://www.fres.co.id 